\title{
Peptides and proteins regulating food intake: a comparative view
}

Marnix H.A.G. Gorissen, Gert Flik and Mark O. Huising

Department of Animal Physiology, Radboud University Nijmegen, Toernooiveld 1, 6525 ED Nijmegen, The Netherlands.

Correspondence should be addressed to:

Mark Huising

E-mail: m.huising@science.ru.nl 


\section{Abstract}

Energy homeostasis is under multiple endocrine and neural control that involves both central and peripheral hormones and neuropeptides. Disorders of energy balance (e.g. obesitas and anorexia nervosa) are caused by subtle dysregulations of these regulatory mechanisms. The hypothalamic arcuate nucleus is a main site of central regulation, where two distinct subpopulations of neurons co-express either neuropeptide Y (NPY) and agouti related protein (AgRP) or proopiomelanocortin (POMC) and cocaine and amphetamine regulated transcript (CART); the former set of peptides increase food intake, the latter decrease food intake and obviously affect energy metabolism. Key peripheral hormones affecting energy metabolism include cholecystokinin (CCK), leptin and insulin which decrease food intake and ghrelin that increases food intake. CCK and ghrelin regulate food intake on the short term (by affecting meal size), whereas leptin and insulin regulate food intake over longer periods spanning several meals. These signals and their physiology are reasonably well-understood in mammals. On the other hand, knowledge on energy metabolism in earlier vertebrates is scant. Recently characterized central food intake regulatory mechanisms in fish suggest that they operate in a manner similar to their mammalian counterparts. Peripheral mechanisms have been poorly studied outside mammals. The recent identification of leptin in several fish species provides new insights and opportunities to enhance our understanding of the regulation of food intake. Comparative analysis of these peripheral mechanisms may shed new light on the function and evolution of the mechanisms at the basis of energy homeostasis. In this review, we summarize the recent developments in understanding of the mechanisms and signals that regulate energy balance in mammals, and compare these to what we now know about their orthologues in earlier vertebrates, with a particular focus on bony fishes.

Keywords: food intake, energy balance, peptides, hormone, leptin. 


\section{Introduction}

All animals have to eat. Homeostasis of energy reserves requires a careful balance between energy intake and expenditure (Schwartz et al. 2000). Whereas energy intake equals (mainly) food consumption and digestion, energy expenditure is the sum of basal metabolism, physical activity and (for endotherms) thermogenesis (Spiegelman et al., 2001). The daily intake of energy can vary both within and between individuals, as a result of environmental and social factors. On the short-term, mismatches in energy balance may and will occur, but in a healthy animal, energy expenditure in the long-term accurately matches the energy intake over a several meals spanning period (Edholm, 1977). A striking example of this accuracy is given by Seeley and Woods (2003): for a standard human male, a surplus of $0.5 \%$ of the consumed energy per year would result in a yearly weight gain of $0.5 \mathrm{~kg}$. As the average yearly increase of weight in the USA is less than 0.5 $\mathrm{kg}$ per adult, this illustrates that subtle dysregulations of the balance between energy input and expenditure are at the basis of the current obesity epidemic in the western society.

In this paper, the regulation of food intake and energy metabolism in mammals is compared to that of non-mammalian vertebrates, with an emphasis on fishes. Attention will be paid to central and peripheral factors that control energy homeostasis. This paper summarizes our contribution to the $12^{\text {th }}$ Benelux congress of zoology held in October 2005. We do not intend to provide an exhaustive review on the regulation of food intake, as this topic has been reviewed elsewhere in great detail; we refer for in-depth reviews to Schwartz et al. (2000) and Seeley and Woods (2003). For an excellent review on regulation of food intake in fish we refer to Volkoff et al. (2005).

Over the years, two alternative viewpoints have existed on the identity of the main peripheral indicator of nutrient status that is perceived by the brain (and the arcuate nucleus (ARC) in the hypothalamus in particular); the lipostatic theory (postulated by Kennedy, 1953) and the glucostatic theory (postulated by Mayer, 1955). The former is based on the hypothesis that the ARC monitors the storage and metabolism of fat, the latter on the hypothesis that the ARC 
monitors storage and metabolism of carbohydrates. The debate has focused on which of these hypotheses provides more insight into the regulation of energy homeostasis. Each theory has its imperfections and cannot fully explain the known variety in feeding behavior or the dynamic energy balance regulation. Seeley and Woods (2003) conclude that the lipostatic and glucostatic theory are not mutually exclusive, and should be appreciated in a coordinate manner. However, in the same review, the role of glucose is downplayed since neurons are generally protected for glucose fluctuations, as it would be catastrophic for neurons to run out of metabolic energy sources. To prevent this from occurring, a decrease in circulating glucose is quickly detected by the liver and the insulin secreting $\beta$-cells in the pancreas, resulting in an immediate increase in plasma glucose and this raises the question if under physiological circumstances glucostatic regulation plays a major role in the central regulation of energy homeostasis. More likely, depletion of glucose in the central nervous system (CNS) triggers an emergency feeding response, and in most situations, fluctuations in basal glucose levels would contribute minimally to the maintenance of energy sources (Seeley and Woods, 2003).

The lipostatic theory received more attention from researchers, ultimately resulting in the discovery of leptin [from the Greek word "leptos", meaning "lean"] (Zhang et al. 1994), a signal molecule produced - in mammals - in peripheral adipose tissue. Leptin signals to the central nervous system, in support of the lipostatic theory. Some fifteen years before the discovery of leptin, insulin (from the Latin word "insula"; island) produced in the pancreatic $\beta$-cells, was one of the first hormonal signals that was implicated in the control of food intake by the CNS (Woods et al. 1979). Leptin and insulin both meet criteria for a candidate adiposity signal as both hormones circulate in quantities proportional to body fat content (Niswender et al., 2004) and enter the CNS in proportion to their plasma level (Schwartz et al., 2000). Furthermore, receptors for insulin and leptin are present in brain areas involved in the regulation of food intake and energy metabolism (Schwartz et al., 2000). The question that remains is how the lipostatic and glucostatic pathways are integrated. 


\section{Central regulation}

The central regulation of appetite and body weight is a complex phenomenon involving interactions between the CNS and the periphery. In the hypothalamus, the ARC plays a central role in this regulation, expressing orexigenic and anorexigenic peptides. The ARC contains two distinct populations of neurons, one which co-expresses neuropeptide Y (NPY) and Agoutirelated protein (AgRP) (Broberger et al., 1998) and is orexigenic, and the other which expresses Cocaine and Amphetamine Regulated Transcript (CART) and pro-opiomelanocortin (POMC; the precursor of $\alpha$-Melanocyte Stimulating Hormone [ $\alpha-\mathrm{MSH}]$ ) (Elias et al., 1998) and is reciprocally anorexic. The $\mathrm{NPY}^{+} / \mathrm{AgRP}^{+}$- and the $\mathrm{CART}^{+} / \mathrm{POMC}^{+}$-neurons receive multiple inputs from the periphery (Schwartz et al., 2000).

\section{Orexigenic}

NPY

NPY is one of the most potent orexigenic peptides known in mammals and is expressed in key areas in the hypothalamus involved in the regulation of food intake (Halford et al., 2004) including the paraventricular nucleus (PVN) and ARC (Kalra et al., 1999). The orexigenic actions of NPY have been investigated thoroughly over the past decades. Injection of NPY into the third ventricle of the brain or directly into the hypothalamus increases food intake in rats (Clark et al., 1985 and 1987). As is expected from a physiological signal, the rise in food intake is dose dependent, with an optimum and a decrease of efficiency at high doses (Clark et al., 1987). Rats are nocturnal animals that feed predominantly in the dark. Continuous central infusion of NPY during the day light period reproduced the characteristic nocturnal feeding behavior in rats, and food intake, frequency of feeding and eating rate $(\mathrm{g} / \mathrm{min})$ were affected in a dose-dependent manner (Kalra et al., 1988). Immunoneutralization of NPY blocked feeding behavior in rats (Dube et al., 1994) and NPY levels increased in response to fasting and decreased upon refeeding 
(Sahu et al., 1988). NPY receptor $\left(Y_{1}\right.$ receptor) mRNA expression was augmented in response to fasting (Xu et al., 1998).

Intracerebroventricular (i.c.v.) administered NPY induces lipogenic enzymes in the liver and white adipose tissue (Billington et al., 1991), thereby increasing anabolic activity. This seems a sensible approach considering that a rise in NPY-levels reflects a reduction in energy reserves, and thus the need to preserve remaining energy stores as well as increase energy consumption. Indeed, peripheral adiposity signals (leptin; insulin) decrease NPY mRNA expression (Stephens $e t$ al., 1995; Schwartz et al., 1996) and an absence of peripheral signals like leptin and insulin increases NPY mRNA expression and secretion (Kalra et al., 1991).

Surprisingly, NPY knock-out mice show essentially normal body weight regulation (Erickson et al., 1996; Ste. Marie et al., 2005). One explanation for this phenomenon is that compensatory mechanisms, either cell-autonomous or circuit-based, are engaged in the absence of NPY. Since NPY producing cells in the ARC also produce AgRP (orexigenic), AgRP could mediate cell-autonomous compensatory mechanisms. However, mice lacking both NPY and AgRP also have normal body weight regulation (Qian et al., 2002), although these mice fail to respond to the orexigenic effects of ghrelin (Chen et al., 2004). Also, the discovery that $\mathrm{NPY}^{+} / \mathrm{AgRP}^{+}$-neurons produce GABA (Horvath et al., 1997), leaves open the possibility of GABA-mediated, cell-autonomous compensation. In addition to cell-autonomous compensation, circuit based compensation may underlie the normal phenotype of NPY null mice. E.g., a decreased $\alpha-\mathrm{MSH} / \mathrm{CART}$ signaling may compensate for the absence of the orexigenic NPY signal (Schwartz et al., 2003).

Besides direct effects on food intake and body weight regulation, NPY is known to stimulate appetitive behavior (Ammar et al., 2000; van Dijk and Strubbe, 2003). I.c.v. NPY infusion stimulated the responses to obtain food, but inhibited those used to consume food (Ammar et al., 2000). Direct infusion of NPY into the PVN of Wistar rats stimulated feeding behavior during the early part of the light phase (van Dijk and Strubbe, 2003). 
NPY has been detected and characterized in several fish species, including goldfish (Carassius auratus), European sea bass (Dicentrarchus labrax) (Cerdá-Reverter et al., 2000), rainbow trout (Oncorbynchus mykiss) (Doyon et al., 2003) and common carp (Cyprinus carpio) (accession number Q9DGK7) and the actions of NPY in fish resemble those in mammalian species. Central administration of homologous and heterologous NPY in fish species increases food intake in a dose-dependent manner (Lopez-Patino et al., 1999; Silverstein et al., 2000) and starvation for several days induces an increase in hypothalamic NPY expression (Silverstein et al., 1999; Narnaware et al., 2001). Refeeding reverses the effects of starvation on NPY peptide levels and mRNA expression (Narnaware et al., 2000; 2001).

\section{Agouti and Agouti Related Protein}

The agouti lethal $\left(\mathrm{A}^{\mathrm{Y}} / \mathrm{a}\right)$ phenotype in the mouse displays a characteristic yellowish fur compared to wild-type (black/brown) mice, in combination with hyperphagia and obesity. This phenotype is the result of ubiquitous expression of the agouti gene (designated agouti signaling protein ASP - in species other than mouse), among others resulting in hyperphagia, hyperinsulinemia and increased linear growth (Michaud et al., 1993; Miller et al., 1993). The yellow fur color is the direct result of the blocking of the melanocortin 1 receptor (MC1R) by agouti, preventing $\alpha$-MSH induced melanization. The obesity associated with $\mathrm{A}^{\mathrm{Y}} / \mathrm{a}$-mice results from agouti antagonizing $\alpha$ MSH signaling in the hypothalamus at the MC4R. A second, agouti related protein (AgRP) which is co-expressed with NPY in a population of neurons in the ARC (Hahn et al., 1998) was subsequently discovered as the endogenous antagonist at the MC3R and MC4R. This AgRP inhibits the anorexigenic effects of $\alpha$-MSH (MacNeil et al., 2002) which are described elsewhere in this review.

Orthologues of both agouti and AgRP have been identified in fish. AgRP has been characterized in several fish species, viæ. goldfish (Cerdá-Reverter et al., 2003), zebrafish (Danio rerio) (Song et al., 2003) and pufferfish (Takifugu rubripes) (Klovins et al., 2004). Fasting up-regulates 
AgRP mRNA levels in the hypothalamus of goldfish and zebrafish (Cerdá-Reverter et al., 2003; Song et al., 2003).

Recently, ASP, an agouti orthologue, was characterized in the goldfish (Cerdá-Reverter et al., 2005). Goldfish ASP is expressed in the skin on the ventral, but not the dorsal side of the body. Furthermore, it was demonstrated that goldfish ASP antagonized $\alpha-\mathrm{MSH}$ binding and activation on the puffer MC1R and the goldfish MC4R and blocked $\alpha$-MSH induced melanophore dispersion in the medaka (Oryzias latipes) melanophore. These data elegantly provide a visualization of the antagonistic networks which also play a major role in the regulation of energy balance. It is striking that two very distinct functions (regulation of skin color and feeding) are carried out by related signaling systems.

\section{Anorexigenic}

\section{CART}

CART peptide was first identified in the 1980s in ovine hypothalamic extracts (Spiess et al., 1981). Douglass et al. (1995) demonstrated that CART mRNA was upregulated after administration of psychostimulant drugs such as cocaine and amphetamine (giving CART its name). Although involvement of CART in activation of the hypothalamus-pituitary-adrenal-axis was recently demonstrated (Smith et al., 2004), CART is best known as an anorectic peptide. The mechanism by which CART evokes its anorectic actions is poorly understood, owing largely to the fact that no receptor has been identified for CART.

I.c.v. administration of CART antibodies increased feeding in rats (Lambert et al., 1998; Kristensen et al., 1998) and i.c.v. injection of recombinant CART prevented feeding (Kristensen et al., 1998), and reversed feeding induced by NPY infusion. Receptors for leptin are present on CART $^{+}$-neurons (Elias et al., 1998). Larsen et al. (2000) showed that continuous i.c.v. administration of CART decreased feeding and body weight in a dose-dependent fashion, although the effects were limited to the first four to five days of treatment. This may imply a 
short-term role in feeding behavior for CART peptides. Aja et al. (2001) show that i.c.v. injection of CART in the lateral ventricle decreases feeding behavior and thus food intake. I.c.v. administration of CART in the fourth ventricle (hindbrain) reduces feeding behavior (Zheng et al., 2001; Aja et al., 2002) and produces taste aversion conditioning (Aja et al., 2002). These observations suggest that CART works at at least two sites: the hypothalamus and the hindbrain.

Goldfish have two CART peptide precursors, pro-CART I and pro-CART II (Volkoff et al., 2001) and both have a widespread distribution in the brain, pituitary and several peripheral tissues including gonads and kidney. No data are yet available of i.c.v. administration of goldfish CART, but i.c.v. injection of human CART (both CART $_{62-76}$ and CART $_{55-102}$, which are two different mature CART peptides derived from the same protein precursor) results in decreased food intake (Volkoff et al., 2000). Food deprivation and refeeding increase CART mRNA two hours after a meal for pro-CART I, whereas pro-CART II expression shows no changes in the brain, although food deprivation induces a decrease of pro-CART II in the olfactory bulbs (Volkoff et al., 2000).

POMC (a-MSH)

The melanocortin peptides comprise adrenocorticotropic hormone (ACTH) and the melanocyte-stimulating hormones $(\alpha-, \beta$ - and $\gamma$-MSH). They are derived from the hormone precursor pro-opiomelanocortin (POMC) (For a detailed review we refer to Dores et al., 2005) by processing by prohormone convertases 1 and 2 (PC1 and PC2). Tissue-specific expression of PC's leads to ACTH production in the corticotrope cells and $\alpha$-MSH in the melanotrope cells of the pituitary (Castro et al., 1997). These peptides are involved in steroidogenesis and skinpigmentation respectively (for a review on melanocortins see: Metz et al., 2006 in press). Since these first observations, many other physiological functions were discovered, including regulation of feeding and energy homeostasis (Panksepp et al., 1976). Indeed, $\mathrm{POMC}^{+}$neurons in the ARC produce $\alpha$-MSH (Elias et al., 1998) in rats. The physiological basis for these effects is attributed to 
the melanocortin receptor 4 (MC4R). Targeted disruption of MC4R in mice led to increased food intake and body weight which is not reduced after administration of a synthetic MCR agonist (Huszar et al., 1997; Marsh et al., 1999). The MC3R is expressed in many brain areas, and MC3R deficient mice show increased fat mass, increased leptin and insulin plasma levels.

The melanocortin system is tightly linked to other systems involved in food intake and energy balance. Melanocortins and NPY have opposite effects on food intake and NPY has an inhibitory effect on POMC expression (Rahmouni et al., 2001).

$\mathrm{POMC}^{+}$neurons express the leptin receptor (Cheung et al., 1997) and leptin administration increases POMC expression in the ARC nucleus (Thornton et al., 1997) and decreases food intake, and results in weight loss (Neary et al., 2004). On the other hand, white fat - which is the major tissue that produces leptin - expresses at least two MCRs, vir. MC2R and MC5R (Chhajlani, 1996) which play a role in lipolysis. The ligands for these receptors, ACTH and $\alpha$-MSH respectively, have potent lipolytic effects (Boston, 1999; Brennan et al., 2003).

Although the melanocortin system in fish is well characterized (for a detailed review of the melanocortin system in fish, we refer to Metz et al., 2006 in press), little is known about the role of $\alpha$-MSH in control of food intake in fish. Cerdá-Reverter et al. (2003a) demonstrate MC4R expression in key areas for food intake control in the goldfish brain. In contrast to mammals, the MC4R in fish is also expressed in the periphery, including spleen, gill and head kidney (Haitina et al., 2004). This indicates that the MC4R may have additional functions in non-mammalian species compared to mammals. I.c.v. administration of MC4R agonists and antagonists resulted in inhibition or stimulation of food intake, respectively, in 24 hours fasted goldfish. Fasting does not modify hypothalamic POMC mRNA expression in the goldfish (Cerdá-Reverter et al., 2003b). These results suggest that $\mathrm{POMC}^{+}$neurons exert a tonic inhibitory effect on food intake, which can be overruled by MC4R antagonists, such as AgRP. However, as POMC is produced at several other nuclei, including the NPO, where it is processed into ACTH (Metz et al., 2004), the 
assessment of POMC gene expression may in this particular case be a poor indicator of the role of $\alpha$-MSH on food intake.

\section{$\mathrm{CRH}$}

The Corticotropin Releasing Hormone (CRH) system comprises a family of peptides (CRH, urocortins I, II and III, urotensin I (in fish) and the amphibian peptide sauvagine), two CRHreceptors and a CRH binding protein (CRH-BP). The CRH system is primarily recognized for its key role in the endocrine regulation of the stress response via the HPA-axis throughout vertebrates (Bale et al., 2004; Huising et al., 2004).

However, extra-HPA activities have also been reported, including regulation of energy balance and food intake in both mammals and fish (Richard et al., 2000; Bernier et al., 2001; Bernier, 2006). Chronic i.c.v. administration of CRH prevents further weight gain in the obese Zucker rat (Rohner-Jeanrenaud et al., 1989). $\mathrm{CRH}_{6-33}$, a CRH fragment that preferentially binds to CRH-BP and antagonizes its action reduces weight gain in the obese $f a / f a$ Zucker rats (Heinrichs et al., 1996) and decreases food intake in ob/ob (leptin deficient) mice (Heinrichs et al., 2001), suggesting a role for CRH-BP in energy homeostasis, probably by modulating the anorectic actions of $\mathrm{CRH}$ and $\mathrm{CRH}$ paralogs. A link between leptin and CRH has been suggested by Arvaniti and co-workers (2001), as they demonstrate that in obese mice, leptin decreases CRH mRNA expression in the PVN.

$\mathrm{CRH}$ has been identified in several fish species, including common carp (Huising et al., 2004), goldfish (Bernier et al., 1999) and Mozambique tilapia (Oreochromis mossambicus) (Van Enckevort et al., 2000). The CRH-like peptides urotensin I (Lederis et al., 1982; Barsyte et al., 1999), orthologues of urocortin II and urocortin III (Lewis et al., 2001; Boorse et al., 2005), the receptors CRH-R1 and CRH-R2 (Huising et al., 2004; Cardoso et al., 2003) and CRH-BP (Huising et al., 2004; Doyon et al., 2005) complete the CRH system in fish. In fish, as in other vertebrates, 
CRH is the dominant hypothalamic hormone controlling the stress axis (Wendelaar Bonga, 1997; Huising et al., 2004; Flik et al., 2006).

In goldfish, i.c.v. injections of CRH and UI dose-dependently suppress food intake, with UI being more potent then CRH (De Pedro et al., 1993; Bernier et al., 2001). These effects can be reversed by pre-treatment with the $\mathrm{CRH}-\mathrm{R}$ antagonist $\left(\alpha\right.$-helical $\left.\mathrm{CRH}_{9-41}\right)$ (De Pedro et al., 1997; Bernier et al., 2001). These results indicate that the CRH system is involved in the regulation of food intake in fish.

Physiologically, the stress-related and the energy homeostatic effects of $\mathrm{CRH}$ may be linked; in socially subordinate rainbow trout, food intake is decreased compared to that in dominant individuals, possibly as a result of an increase in CRH mRNA levels in the nucleus preopticus (NPO) (Doyon et al., 2003). This seems reasonable, as the most important objective for a stressed animal is to cope with the stressor, and energy consuming processes such as reproduction and the search for food will be temporarily arrested. So, CRH may activate the HPA axis, and simultaneously decrease feeding behavior when the organism is stressed.

\section{Integration of hypothalamic signals}

[Figure 1 in this paragraph]

The integration of all peripheral information regarding energy supplies is mediated by a highly complex hypothalamic circuit that consists of several hypothalamic nuclei including the PVN, periformical area (PFA) and the lateral hypothalamic area (LHA), which are richly supplied by axons from $\mathrm{ARC} \mathrm{NPY}^{+} / \mathrm{AgRP}^{+}$and $\mathrm{POMC}^{+} / \mathrm{CART}^{+}$neurons (Elmquist et al., 1998; 1999). Neurons in the PVN produce several neuropeptides that reduce food intake and body weight when administrated centrally, such as $\mathrm{CRH}$, thyrotropin-releasing hormone (TRH) and oxytocin (Kow et al., 1991; Verbalis et al., 1995). On the other hand, the LHA and PFA produce several food intake increasing neuropeptides, such as melanin-concentrating hormone (MCH) (Qu et al., 1996) and orexins A and B respectively (de Lecea et al., 1998; Sakurai et al., 1998). The fact that 
both ARC cell types project to the PVN, has led to the suggestion that neurons in the PVN, that express the receptors for both NPY and $\alpha-\mathrm{MSH}$, can detect and integrate orexigenic (NPY, AgRP) and anorexigenic (melanocortins) signals (Cowley et al., 1999). The hypothalamic signals are integrated in the hindbrain, PVN signals stimulate, and PFA and LHA signals inhibit the termination of individual meals respectively (Schwartz et al., 2000).

CART influences metabolic rate via thyroid hormone; CART releases TRH from hypothalamic explants (Stanley et al., 2001) and inhibits suppression of TRH in the PVN of fasted rats (Fekete et al., 2000). Conversely, hyperthyroidism decreases expression of CART in the PVN (Lopez et al., 2002), establishing CART as a mediator of metabolic regulation.

$\alpha-\mathrm{MSH}$ modulates thyroid hormone levels and fat metabolism. The MC4R is expressed on TRH-producing cells in the PVN (Fekete et al., 2000) and $\alpha$-MSH has a stimulatory effect on preproTRH gene transcription and thus $\alpha$-MSH increases levels of thyroid hormone via the hypothalamus-pituitary-thyroid (HPT) axis. Thereby, $\alpha-\mathrm{MSH}$ increases metabolic activity when the animal is fed and decreases metabolic activity when the animal is fasted, which is a crucial survival mechanism.

\section{Peripheral regulation of food intake and body weight}

To achieve energy homeostasis, meal size and meal frequency are regulated. Both the initiation of a meal, and the termination of a meal are biologically controlled processes. Whereas the endocrine initiation of a meal has only recently been established and is controlled by ghrelin (Tshöp et al., 2000; Lawrence et al., 2002; Chen et al., 2004), termination of a meal (through satiation/satiety) is a process known for several decades and is controlled by CCK (Gibbs et al., 1973). Ghrelin is released upon the absence of nutrients in the stomach and activates the $\mathrm{NPY}^{+} / \mathrm{AgRP}^{+}$neurons in the ARC (Chen et al., 2004) and thus food intake. CCK is released upon stimulation by nutrients in the stomach and is transmitted by vagal efferents to the 
hindbrain (Moran and Kinzig, 2004; Little et al., 2005). Ghrelin and CCK will be discussed in the next paragraphs.

Regulation of body weight is achieved through regulation of food intake (and the regulation of energy expenditure). Information regarding prevailing energy reserves is transmitted to the CNS by at least two signals, vir. leptin and insulin. These hormones both circulate in proportion to body fat, cross the blood-brain-barrier, and activate the $\mathrm{POMC}^{+} / \mathrm{CART}^{+}$neurons and inactivate the $\mathrm{NPY}^{+} / \mathrm{AgRP}^{+}$neurons. Since leptin and insulin signal information regarding body fat (i.e. energy stores) these hormones may be considered as peripheral regulators of body weight and energy reserves. Both hormones will be discussed below in addition to CCK and ghrelin, which are important hormones for the regulation of food intake.

\section{Food intake regulation}

\section{CCK}

Cholecystokinin (CCK) is found in both the brain and the gastrointestinal tract (Moran and Kinzig, 2004). In the brain, CCK functions as a neurotransmitter and has effects on diverse behaviors including satiety (Crawley and Corwin, 1994). Within the gastrointestinal tract, CCK is found in neural and endocrine cells. Endocrine cells containing CCK (I-cells) are stimulated by intestinal nutrients and secrete their product in the blood and/or surrounding tissue (Moran and Kinzig, 2004). CCK is also present in enteric vagal afferent neurons where it acts as a neurotransmitter (Larson and Rehfeld, 1979).

CCK comes in multiple molecular forms (Rehfeld, 1981; Eberlein et al., 1992; Rehfeld, 1998), classified according to the number of amino acids they contain, which are all derived from a 95 amino acid proCCK (Rehfeld, 1998).

Two types of CCK receptors have been identified to date, originally named CCK-A (alimentary type) and CCK-B (brain type), according to their anatomical distribution (Moran et al., 1986; Wank et al., 1992; Little et al., 2005). More recently, it has been established that there is 
overlap in their anatomical distribution and the CCK-A and CCK-B receptors are renamed $\mathrm{CCK}_{1}$ and $\mathrm{CCK}_{2}$ receptors respectively (Moran and Kinzig, 2004; Little et al., 2005). The $\mathrm{CCK}_{1}$ receptor is expressed in several brain areas involved in the regulation of food intake, including the nucleus tractus solitarius (NTS) (Moran et al., 1986; Hill et al., 1987), and has high (adapted to respond to low concentrations of CCK; pM range) and low (adapted to respond to high concentrations of CCK; nM range) affinity binding sites (Pandya et al., 1994; Little et al., 2005). In rats, the inhibitory effect of CCK on food intake has been shown to be mediated by activation of the low affinity binding sites of the $\mathrm{CCK}_{1}$ receptor (Weatherfort et al., 1993). This has a major implication, as it is unlikely that postprandial concentrations of CCK occur in the range of nM. This suggests that the satiety effects of CCK are not endocrine, but must reflect higher CCK concentrations at local sites of action (Moran and Kinzig, 2004).

In their landmark study, Gibbs and co-workers (1973) demonstrated that intraperitoneal administration of the sulfated octapeptide of CCK (CCK-8) dose-dependently decreased intake of solid and liquid food in rats. CCK-8 reduced both the size, and the duration of a meal. CCK affects food intake rapidly, and the duration of the inhibition is relatively short. Therefore, CCK reduces single meal size, but does not affect total daily intake because reduced meal size is compensated by an increase in the number of meals (West et al., 1984).

CCK immunoreactivity has been detected in several fish species, including Atlantic cod (Jonsson et al., 1987) and goldfish (Himick and Peter, 1994). CCK mRNA have been shown in several fish species, including goldfish, rainbow trout (Jensen et al., 2001), pufferfish and flounder (Kurokawa et al., 2003).

Fish possess different CCK-8 peptides that differ in amino acid number six, counting from the C-terminus. Although CCK-8 is the major product of posttranslational processing of CCK, other CCK forms (e.g. CCK-7, CCK-21) have been detected in rainbow trout, which are all fully sulfated (Johnsen et al., 1998; Jensen et al., 2001). 
In fish, CCK is released when food is present in the gastrointestinal tract (Aldman and Holmgren, 1995). CCK has been shown to suppress food intake in fish; i.c.v. and i.p. injections of sulfated CCK-8 in goldfish decrease food intake (Himick and Peter, 1994; Volkoff et al., 2003) and administration of CCK antagonists increase food intake in rainbow trout (Gélineau and Boujard, 2001). CCK mRNA increases 2 hours postprandially in the goldfish brain (Peyon et al., 1999).

\section{Ghrelin}

Ghrelin is a 28 amino acid peptide that is predominantly produced in the stomach and was identified as the endogenous ligand for the growth hormone secretagogue receptor (GHS-R) in 1999 by Kojima and co-workers (Kojima et al., 1999) ("ghre" is the Proto-Indo-European root for "grow"). It contains a unique fatty acid side-chain on the third amino acid residue which is necessary for most of its biological activity. In human, this modification is an octanoyl (C8) sidechain (Kojima et al., 1999).

Ghrelin-immunoreactive cells are found predominantly in the stomach, but also in the duodenum, ileum, colon, hypothalamus and pancreas (in the newly identified epsilon $(\varepsilon)$ cells). In the intestine, ghrelin-immunoreactivity decreases from the duodenum to the colon (Kojima et al., 2005).

Ghrelin controls energy homeostasis by increasing food intake (Tschöp et al., 2000; Nakazato et al., 2001; Lawrence et al., 2002) and is a potent peripheral orexigenic hormone.

Although ghrelin is widely regarded as a peripherally expressed peptide, in a recent paper by Cowley et al. (2003), ghrelin expression is detected in previously uncharacterized hypothalamic neurons that are adjacent to the third ventricle between the dorsal, ventral PVN and ARC. In the ARC, these ghrelin-expressing neurons project to the $\mathrm{NPY}^{+} / \mathrm{AgRP}^{+}$-neurons to stimulate the release of these orexigenic peptides and to the $\mathrm{POMC}^{+} / \mathrm{CART}^{+}$-neurons to suppress the release 
of these anorexigenic peptides. Although identified as a peripheral orexigenic signal, ghrelin in the hypothalamus is positioned such that it can regulate food intake directly.

Ghrelin has been identified in several teleost fish species, including goldfish (Unniappan $e t$ al., 2002), Mozambique tilapia (Kaiya et al., 2003a), Japanese eel (Anquilla japonica) (Kaiya et al., 2003b), and rainbow trout (Kaiya et al., 2003c) with high expression levels in the stomach(/gut) and moderate levels in the brain. Fish ghrelins come in multiple forms that vary in length, in the specific fatty acid modifications on the third amino acid (octanoyl; C8 or decanoyl; C10) and in the presence of an amide structure at the C-terminal end (Kaiya et al., 2003a; 2003b; 2003c).

Recent studies demonstrate that similar to mammals, ghrelin in fish is involved in feeding and energy homeostasis (Unniappan et al., 2002; Riley et al., 2005). Both central and peripheral injections of homologous ghrelin in goldfish stimulate food intake (Unniappan et al., 2002). A postprandial decrease in preproghrelin mRNA expression in the hypothalamus and gut and a subsequent decrease in serum levels of ghrelin further support the orexigenic actions of ghrelin in goldfish (Unniappan et al., 2004). In tilapia, long-term treatment by osmotic mini pump (21 days) of homologous ghrelin-C8 and ghrelin-C10 result in different effects (Riley et al., 2005). Whereas food consumption, fat deposition, liver weight and total fat content in the liver increased, and plasma IGF-I decreased in animals that received ghrelin-C10, ghrelin-C8 did not affect any of these parameters. Ghrelin-C8 did increase GH mRNA expression in the pituitary (although no longitudinal growth was observed between the ghrelin treated groups and the controls), suggesting differential functions for ghrelin-C8 and ghrelin-C10, perhaps via different ghrelin receptor isoforms. Furthermore, these data suggest that the orexigenic actions of ghrelin are independent of its ability to increase plasma GH levels (Riley et al., 2005). More work is needed to characterize the ghrelin receptor isoforms in the tilapia. The fact that ghrelin-C10 is the major circulating form of ghrelin in tilapia (Kaiya et al., 2003a) may reflect a more important role in this species for ghrelin in energy homeostasis than its GH releasing role, although ghrelin-C8 expression may be restricted to hypothalamic nuclei; indeed a low ghrelin mRNA expression is 
detected by RT-PCR in the brain (Kaiya et al., 2003a, b, c). Contrasting mammalian studies, peripheral ghrelin-C10 in tilapia decreases plasma levels of IGF-I (Riley et al., 2005). This finding suggests that ghrelin may possess distinct physiological functions in fish (ectotherms) that differ from those seen in mammals (endotherms) where the allocation of energy might be different.

Recently, Iqbal et al. (2006) demonstrate that injection of ovine ghrelin into the third ventricle is unable to stimulate voluntary food intake in sheep, in contrast to the other mammalian species investigated so far. This finding is even more puzzling, since a rise in ghrelin plasma levels is seen in sheep before feeding (Sugino et al., 2002; 2004), as in other mammalian species (Tschöp et al., 2000; Cummings et al., 2003). The different response to ghrelin between sheep and other mammals may lie in the fact that sheep are ruminants, whereas the other mammals studied (rat, mice and human) are monogastric. In sheep, ghrelin is produced in the abomasum (Hayashida et al., 2001) (the fourth stomach of ruminants) in contrast with monogastric species, where ghrelin is produced in the proximal part of the stomach. The rumen (first stomach) is not emptied between meals and these ruminant characteristics may underline the differences observed in ghrelin effects in these species. Iqbal et al. (2006) observe a postprandial rise in GH levels, and it is likely that ghrelin (that was initially discovered as an inducer of $\mathrm{GH}$ secretion) regulates central GH secretion.

\section{Body weight regulation}

\section{Leptin}

Three decades ago, parabiosis experiments (where two mice or rats are surgically joined to allow the passage of circulating signals) with $o b / o b$ mice (a mutant genotype marked by intense hyperphagia and obesity) and wild-type littermates suggested the absence of a circulating factor in the $o b / o b$ mice responsible for the hyperphagia and obesity (Coleman et al. 1969; 1973).

Indeed, twenty years later, Zhang and co-workers (1994) demonstrated that the hyperphagia and obesity observed in $o b / o b$ mice resulted from a recessive mutation of the obese 
gene. This gene encodes a unique member of the class-I $\alpha$-helical cytokine family, a $16 \mathrm{kDa}$ protein which was named leptin and is secreted (mainly) by white adipose tissue. This makes leptin a perfect candidate to inform the brain about nutritional status and reserves. Indeed, leptin is shuttled across the blood brain barrier by a trunctuated form of the leptin receptor (Kastin et al., 1999) and leptin receptors are present on the $\mathrm{NPY}^{+} / \mathrm{AgRP}^{+}$-neurons and the $\mathrm{POMC}^{+} / \mathrm{CART}^{+}$-neurons (Schwartz et al., 2000; Leibowitz et al., 2004) and this suggests that leptin affects food intake by simultaneously stimulating anorexigenic factors and inhibiting orexigenic factors. In-vivo experiments confirm that this is indeed true as administration of leptin, both peripherally and centrally, reduces food intake in mammals. Even more importantly, leptin is secreted into the bloodstream in proportion to the total amount of body fat (Schwartz et al., 2000; Niswender et al., 2004), and is therefore a reliable indicator of available energy reserves.

Until the recent identification of a cDNA encoding leptin in pufferfish (Kurokawa et al., 2005) and duplicate leptin genes in common carp (Huising et al., 2006), leptin had only been isolated in mammals. Kurokawa et al. also performed a database search and found leptin in several other fish species (Medaka, Atlantic salmon (Salmo salar) and freshwater puffer; Tetraodon nigroviridis) and amphibians (Xenopus tropicalis and Ambystoma tigrinum). The deduced amino acid sequence of puffer leptin is only $13.2 \%$ identical to human leptin. In fact, leptin is one of the class-I helical cytokines with the poorest primary sequence conservation throughout vertebrates (Huising et al., 2006). However, the conservation of a pair of cysteine residues that forms a disulphide bond, conservation of gene structure, phylogenetic analyses and a predicted conservation of tertiary structure (four $\alpha$-helices) between fish and mammalian leptin confirms that fish leptins are true orthologues to leptin of mammalian species (Kurokawa et al., 2005; Huising et al. 2006 in press; Huising, pers. observation.). Puffer leptin is expressed mainly in the liver, whereas the main site of mammalian leptin expression is fat tissue. Interestingly, the hepatocytes of puffer contain abundant oil droplets reminiscent of adipocytes. 
Leptin-like immunoreactivity was detected in several fish species in the blood, liver and adipocytes, including burbot (Lota lota) and sea lamprey (Petromyzon marinus) (Johnson et al., 2000; Yaghoubian et al., 2001; Mustonen et al., 2002; Vegusdal et al., 2003). In goldfish, both peripheral and central injections of murine leptin decrease food intake (Volkoff et al., 2003). In the same study, it was found that higher doses of peripheral injection are required to exert the same effects as central injections, which suggests that in fish, as in mammals, leptin exerts at least part of its actions in the brain. Injections of murine leptin decrease NPY mRNA expression in the goldfish brain whereas CART and cholecystokinin (CCK) mRNA is upregulated (Volkoff et al., 2001; 2003). These data suggest that in fish, leptin also interacts with hypothalamic nuclei to inhibit food intake. However, now that we are aware of the poor primary sequence conservation between fish and mammalian leptins, we should interpret these effects of mammalian leptin on food intake in fish, as well as the immunoreactivities detected with antibodies against human or mouse leptin, with caution. Therefore, the recent identification of leptin in fish will provide new insights and possibilities for research considering the regulation of food intake in fish, and new understandings of the evolution of leptin and the role(s) it plays in energy metabolism throughout vertebrates.

The first experiments assessing the function of carp leptin suggest that (at least in this species) leptin is important for the regulation of food intake, but not for body weight (Huising et al., in preparation). We interpret these findings in light of the ectothermic metabolism of fish which allows many species of fish to respond to fluctuations in food availability by arrested or accelerated growth.

\section{Insulin}

Although leptin has lately received the lion's share of the attention of researchers, insulin, produced by the pancreatic $\beta$-cells, was on of the first peripheral signal described to be involved in the regulation of food intake. Woods and co-workers demonstrated in 1979 that chronic i.c.v. 
administration of insulin reduces food intake and body weight in baboons. Entry of insulin in the brain has been demonstrated in several species, including dog, rodents and human (Baura, et al., 1993; Schwartz et al., 2000). Insulin receptors have been characterized in the brain, also in key areas for the regulation of food intake, including the ARC (Wilcox et al., 1989).

Demonstration that insulin signaling in the CNS affects food intake and energy homeostasis is more complicated than doing so for leptin, since insulin fluctuations directly modulate plasma glucose (by mediating glucose uptake in muscle and liver) and low glucose itself is a signal that will increase food intake; the reverse occurs at high glucose concentrations (Lovett et al., 1970). This complicates the assessment of the direct actions of insulin. Furthermore, animals without insulin or with an insulin receptor deficiency die before reaching adulthood.

However, as i.c.v. insulin administration decreases NPY mRNA and protein levels in the ARC (Schwartz et al., 1992) this suggests a direct anorexic role for insulin. Moreover, direct administration of insulin in the CNS as well as local deletion of insulin receptors in the brain demonstrate a function for insulin in energy homeostasis. When insulin is administered i.c.v., a dose-dependent decrease of food intake and body weight is seen in baboons and rats (Woods et al., 1979; Chavez et al., 1995). The disruption of insulin receptors in neurons in mice results in higher food intake, more body fat and increased weight gain (Brüning et al., 2000).

In fish, especially compared to mammals, insulin seems to play important roles in lipid and protein metabolism (Ince, 1983; Plisetskaya, 1990) and free amino acids are the most potent secretagogues for insulin release in fish species (Mommsen et al., 1991). Possibly because insulin appears to play a less important role in glucose metabolism in fish, the role of insulin in the control of food intake in fish has not been extensively studied. Moreover, as fasting of rainbow trout for six weeks resulted in a decrease of plasma insulin (Moon et al., 1989) and feeding this species with a high carbohydrate diet increased plasma insulin levels (Hilton et al., 1987), insulin seems to be involved in energy homeostasis indeed. More recently, Soengas and Aldegunde (2004) demonstrated that i.c.v. injection of insulin in rainbow trout inhibited food intake after 26 
hours and this effect was still apparent after 74 hours. So, insulin elicits effects on the long term; between hours and days.

\section{Perspectives}

The central mechanisms involved in the regulation of food intake are relatively well characterized in mammals as well as in non-mammals and generally appear to function similarly throughout all vertebrates classes studied to date. On the other hand, our understanding of peripheral regulators of food intake in earlier vertebrates is scarce compared to mammals. Only very recently, with the identification of leptin in fish and the first reports on the food intake regulating actions of ghrelin in fish, new insight and understanding in these mechanisms came into focus. These results suggest that peripheral signals indicating nutrient status differ in their function between endotherm and ectotherm species. These differences may stem from the different management of energy reserves between ectotherms and endotherms, as the latter require much tighter control of food intake to ensure continued thermoregulation (Somero et al., 2005).

Also, the very different actions of ghrelin in ruminants (sheep) and birds (chickens) may give us more understanding in the evolution and function of ghrelin in humans. Now that we know that leptin is poorly conserved from fish to human, studies with homologous leptin are needed to verify previous results obtained with murine leptin administration in fish and to identify new effects of leptin in ectotherm species.

Teleost fish in particular, with an estimated number of as many as 35,000 extant species that have successfully adapted to a large and diverse array of different habitats provide many useful and interesting model systems for comparative studies on energy homeostasis. Peripheral signals such as leptin, ghrelin, and insulin now require our attention, as knowledge on these factors in earlier vertebrates may provide new insights in the evolution of energy metabolism and might reveal clues that assist in our understanding of the ongoing obesity epidemic. 


\section{Literature}

Aja, S., Schwartz, G.J., Kuhar, M.J., Moran, T.H. (2001) Intracerebroventricular CART peptide reduces rat ingestive behaviour and alters licking microstructure. Am. J. Physiol. Regul. Integr. Comp. Physiol., 280, R1613-R1619.

Aja, S., Robinson, B.M., Mills, K.J., Ladenheim, E.E., Moran, T.H. (2002) Fourth ventricular CART reduces food and water intake and produces a conditioned taste aversion in rats. Behav. Neurosci., 116(5), 918-921.

Aldman, G., Holmgren, S. (1995) Intraduodenal fat and amino acids acticate gallbladder motility in the rainbow trout, Onchorbynchus mykiss. Gen. Comp. Endocrinol., 100, 27-32.

Ammar, A.A., Sederholm, F., Saito, T.R., Scheurink, A.J., Johnson, A.E., Sodersten, P. (2000) NPY-leptin: opposing effects on appetitive and consummatory ingestive behavior and sexual behavior. Am. J. Physiol. Regul. Integr. Comp. Physiol., 278, R1627-1633.

Arai, M., Assil, I.Q., Abou-Samra, A.B. (2001) Characterization of three corticotropin-releasing factor receptors in catfish: a novel third receptor is predominantly expressed in pituitary and urophysis. Endocrinology, 142(1), 446-454.

Arvaniti, K., Huang, O.L., Richard, D. (2001) Effects of leptin and corticosterone on the expression of corticotropin-releasing hormone, agouti-related protein, and proopiomelanocortin in the brain of ob/ob mouse. Neuroendocrinology, 73(4), 227-236.

Bale, T.L., Vale, W.W. (2004) CRF and CRF receptors: role in stress responsivity and other behaviours. Annu. Rev. Pharmacol. Toxicol., 44, 525-557. 
Barsyte, D., Tipping, D.R., Smart, D., Conlon, J.M., Baker, B.I., Lovejoy, D.A. (1999) Rainbow trout (Oncorbynchus mykiss) urotensin-I: structural differences between urotensins-I and urocortins. Gen. Comp. Endocrinol., 115(2), 169-177.

Baura, G.D., Foster, D.M., Porte, D., Kahn, S.E., Bergman, R.N., Cobelli, C., Schwartz, M.W. (1993) Saturable transport of insulin from plasma into the central nervous system of dogs in vivo. A mechanism for regulated insulin delivery to the brain. J. Clin. Invest., 92(4), 1824-1830.

Bernier, N.J., Lin, X., Peter, R.E. (1999) Differential expression of corticotropin-releasing factor (CRF) and urotensin I precursor genes, and evidence of CRF gene expression regulated by cortisol in goldfish brain. Gen. Comp. Endocrinol., 116(3), 461-477.

Bernier, N.J., Peter, R.E. (2001) Appetite-suppressing effects of urotensin I and corticotropinreleasing hormone in goldfish (Carassius auratus). Neuroendocrinology, 73(4), 248-260.

Bernier, N.J. (2006) The corticotrophin-releasing factor system as a mediator of the appetite suppressing effects of stress in fish. Gen. Comp. Endocrinol., 146(1), 45-55.

Billington, C.J., Briggs, F.E., Grace, M., Levine, A.S. (1991) Effects of intracerebroventricular injection of neuropeptide Y on energy metabolism. Am. J. Physiol. Regul. Integr. Comp. Physiol., 260, R321-R327.

Boorse, G.C., Crespi, E.J., Dautzenberg, F.M., Denver, R.J. (2005) Urocortins of the South African Clawed Frog, Xenopus laevis: Conservation of Structure and Function in Tetrapod Evolution. Endocrinology, 146(11), 4851-4860. 
Boston, B.A. (1999) The role of melanocortins in adipocyte function. Ann. N. Y. Acad. Sci, 885, 75-84.

Brennan, M.B., Costa, J.L., Forbes, S., Reed, P., Bui, S., Hochgeschwender, U. (2003) Alphamelanocyte-stimulating hormone is a peripheral, integrative regulator of glucose and fat metabolism. Ann. N. Y. Acad. Sci., 994, 282-287.

Broberger, C., Johansen, J., Johansen, C., Schalling, M., Hokfelt, T. (1998) The neuropeptide $\mathrm{Y} /$ agouti gene-related protein (AGRP) brain circuitry in normal, anorectic, and monosodium glutamate-treated mice. Proc. Natl. Acad. Sci. USA., 95(25), 15043-15048

Brüning, J.C., Gautam, D., Burks, D.J., Gillette, J., Schubert, M., Orban, P.C., Klein, R., Krone, W., Müller-Wieland, D., Kahn, C.R. (2000) Role of brain insulin receptor in control of body weight and reproduction. Science, 289, 2122-2125.

Carodso, J.C., Power, D.M., Elgar, G., Clark, M.S. (2003) Isolation and characterisation of the corticotropin releasing factor receptor 1 (CRFR1) gene in a teleost fish, Fugu rubripes. DNA Seq., 14(3), 215-218.

Castro, M.G., Morrison, E. (1997) Post-translational processing of proopiomelanocortin in the pituitary and in the brain. Crit. Rev. Neurobiol., 11, 35-57.

Cerdá-Reverter, J.M., Anglade, I., Martinez-Rodriguez, G., Mauzurais, D., Munoz-Cueto, J.A., Carrillo, M., Kah, O., Zanuy, S. (2000) Characterization of neuropeptide Y expression in the brain of a perciform fish, the sea bass (Dicentrarchus labrax). J. Chem. Neuro-anat., 19, 197-210. 
Cerdá-Reverter, J.M., Peter, R.E. (2003) Endogenous melanocortin antagonist in fish: structure, brain mapping and regulation by fasting of the goldfish agouti-related protein gene. Endocrinology, 144, 4552-4561.

Cerdá-Reverter, J.M., Ringholm, A., Schiöth, H.B., Peter, R.E. (2003a) Molecular cloning, pharmacological characterization, and brain mapping of the melanocortin 4 receptor in the goldfish: Involvement in the control of food intake. Endocrinology, 144, 2336-2349.

Cerdá-Reverter, J.M., Schiöth, H.B., Peter, R.E. (2003b) The central melanocortin system regulates food intake in goldfish. Regul. Peptides, 115, 101-113.

Cerdá-Reverter, J.M., Haitina, T., Shiöth, H.B., Peter, R.E. (2005) Gene structure of the goldfish agouti-signaling protein: a putative role in the dorsal-ventral pigment pattern of fish. Endocrinology, 146(3), 1597-1610.

Chavez, M., Kaiyala, K., Madden, L.J., Schwartz, M.W., Woods, S.C. (1995) Intraventricular insulin and the level of maintained body weight in rats. Behav. Neurosci., 109(3), 528-531.

Chhajlani, V. (1996) Distribution of cDNA for melanocortin receptor subtypes in human tissues. Biochem. Mol. Biol. Int., 38, 73-80.

Chen, H.Y., trumbauer, M.E., Chen, A.S., Weingarth, D.T., Adams, J.R., Frazier, E.G., Shen, Z., Marsh, D.J., Feighner, S.D., Guan, X.M., Ye, Z., Nargund, R.P., Smith, R.G., Van der Ploeg, L.H., Howard, A.D., MacNeil, D.J., Qian, S. (2004) Orexigenic action of peripheral ghrelin is mediated by neuropeptide Y and agouti-related protein. Endocrinology, 145(6), 2607-2612. 
Cheung, C.C., Clifton, D.K., Steiner, R.A. (1997) Proopiomelanocortin neurons are directly targets for leptin in the hypothalamus. Endocrinology, 138, 4489-4492.

Clark, J.T., Kalra, P.S., Kalra, S.P. (1985) Neuropeptide Y stimulates feeding but inhibits sexual behaviour in rats. Endocrinology, 117(6), 2435-2442.

Clark, J.T. Sahu, A., Kalra, P.S., Balasubramaniam, A., Kalra, S.P. (1987) Neuropeptide Y (NPY)induced feeding behavior in female rats: comparison with human NPY ([Met17]NPY), NPY analog. Regul. Pept., 17(1), 31-39.

Coleman, D. L. et al. (1969) Effects of parabiosis of normal with genetically diabetic mice. Am. J. Physiol, 217, 1298-1304.

Coleman, D. L. (1973) Effects of parabiosis of obese with diabetes and normal mice. Diabetologia, 9, 294-298.

Cowley, M.A., Pronchuk, N., Fan, W., Dinulescu, D.M., Colmers, W.F., Cone, R.D. (1999) Integration of NPY, AGRP, and melanocortin signals in the hypothalamic paraventricular nucleus: Evidence of a cellular basis for the adipostat. Neuron, 24, 155-163.

Cowley, M.A., Smith, R.G., Diano, S., Tschöp, M., Pronchuk, N., Grove, K.L., Strasburger, C.J., Bidlingmaier, M., Esterman, M., Heiman, M.L., Garcia-Segura, L.M., Nillni, E.A., Mendez, P., Low, M.J., Sotonyi, P., Friedman, J.M., Liu, H., Pinto, S., Colmers, W.F., Cone, R.D., Horvath, T.L. (2003) The distribution and mechanism of action of ghrelin in the CNS demonstrates a novel hypothalamic circuit regulating energy homeostasis. Neuron, 37(4), 649-661. 
Crawley, J.N., Corwin, R.L. (1994) Biological actions of cholecystokinin. Peptides, 15, 731-735.

Cummings, D.E., Foster, K.E. (2003) Ghrelin-leptin tango in body-weight regulation. Gastroenterology, 124(5), 1532-1535.

De Lecea, L., Kilduff, T.S., Peyron, C., Gao, X., Foye, P.E., Danielson, P.E., Fukuhura, C., Battenberg, E.L., Gautvik, V.T., Barlett, F.S., Frankel, W.N., van den Pol, A.N., Bloom, F.E., Gautvik, K.M., Sutcliffe, J.G. (1998) The hypocretins: hypothalamus-specific peptides with neuroexcitatory activity. Proc. Natl. Acad. Sci. USA, 65(1), 322-327.

De Pedro, N., Alonso-Gomez, A.L., Gancedo, B., Delgado, M.J., Alonso-Bedate, M. (1993) Role of corticotropin-releasing factor (CRF) as a food intake regulator in goldfish. Physiol. Behav., $53(3), 517-520$

De Pedro, N., Alonso-Gomez, A.L., Gancedo, B., Valenciano, A.I., Delgado, M.J., AlonsoBedate, M. (1997) Effect of alpha-helical-CRF[9-41] on feeding in goldfish: involvement of cortisol and catecholamines. Behav. Neurosci., 111(2), 398-403.

Douglass, J., McKinzie, A.A., Couceyro, P. (1995) PCR differential display identifies a rat brain mRNA that is transcriptionally regulated by cocaine and amphetamine. J. Neurosci., 15, 24712481.

Dores, R.M., Lecaude, S. (2005) Trends in the evolution of the proopiomelanocortin gene. Gen. Comp. Endocrinol., 142, 193-205. 
Doyon, C., Gilmour, K.M., Trudeau, V.L., Moon, T.W. (2003) Corticotropin-releasing factor and neuropeptide $\mathrm{Y}$ mRNA levels are elevated in the preoptic area of socially subordinate rainbow trout. Gen. Comp. Endocrinol., 133, 260-271.

Doyon, C., Trudeau, V.L., Moon, T.W. (2005) Stress elevates corticotropin-releasing factor (CRF) and CRF-binding protein mRNA levels in rainbow trout (Oncorbynchus mykiss). J. Endocrinol., 186(1), 123-130.

Dube, M.G., Xu, B., Crowley, W.R., Kalra, P.S., Kalra, S.P. (1994) Evidence that neuopeptide Y is a physiological signal for normal food intake. Brain Res., 646(2), 341-344.

Eberlein, G.A., Eysselein, V.E., Davis, M.T., Lee, T.D., Shively, J.E., Grandt, D., Niebel, W., Williams, R., Moessner, J., Zeeh, J., Meyer, H.E., Goebell, H., Reeve Jr., J.R. (1992) Patterns of prohormone processing. Order revealed by a new procholecystokinin-derived peptide. J. Biol. Chem., 267(3), 1517-1521.

Edholm, O.G. (1977) Energy metabolism in man. J. Human Nutr., 31, 413-431.

Elias, C.F., Lee, C., Kelly, J., Aschkenasi, C., Ahima, R.S., Couceyro, P.R., Kuhar, M.J., Saper, C.B., Elmquist, J.K. (1998) Leptin activates hypothalamic CART neurons projecting to the spinal cord. Neuron, 21(6), 1375-1385.

Elmquist, J., Maratos-Flier, E., Saper, C., Flier, J. (1998) Unraveling the central nervous system pathways underlying responses to leptin. Nature Neurosci., 1, 445-450. 
Elmquist, J., Elias, C., Saper, C. (1999) From lesions to leptin: hypothalamic control of food intake and body weight. Neuron, 22, 221-232.

Erickson, J.C., Hollopeter, G., Palmiter, R.D. (1996) Sensitivity to leptin and susceptibility to seizures of mice lacking neuropeptide Y. Nature, 381, 415-421.

Fekete, C., Mihaly, E., Luo, L.G., Kelly, J., Clausen, J.T., Mao, Q., Rand, W.M., Moss, L.G., Kuhar, M., Emerson, C.H., Jackson, I.M., Lechan, R.M. (2000) Association of cocaine- and amphetamine-regulated transcript-immunoreactive elements with thyrotropin-releasing hormonesynthesizing neurons in the hypothalamic paraventricular nucleus and its role in the regulation of the hypothalamic-pituitary-thyroid axis during fasting. J. Neurosci., 20(24), 9224-9234.

Flik, G., Klaren, P.H.M., Van den Burg, E.H., Metz, J.R., Huising, M.O. (2006) CRF and stress in fish. Gen. Comp. Endocr. In press.

Geelissen, S.M. (2005) Mechanisms involved in the anorexigenic action of ghrelin in chicken. In: Ghrelin, a novel growth hormone secretagogue in chicken: mode of action (thesis), pp. 127-145.

Geelissen, S.M., Swennen, Q., van der Geyten, S.V., Kuhn, E.R., Kaiya, H., Kangawa, K., Decuypere, E., Buyse, J., Darras, V.M. (2006) Peripheral ghrelin reduces food intake and respiratory quotient in chicken. Domest. Anim. Endocrinol., 30(2), 108-116.

Gélineau, A. Boujard., T. (2001) Oral administration of cholecystokinin receptor antagonists increase feed intake in rainbow trout. J. Fish Biol., 58, 716-724. 
Gibbs, J., Young, R.C., Smith, G.P. (1973) Cholecystokinin decreases food intake in rats. J. Comp. Physiol. Psychol., 84, 488-495.

Hahn, T.M., Breininger, J.F., Baskin, D.G., Schwartz, M.W. (1998) Coexpression of AgRP and NPY in fasting-activated hypothalamic neurons. Nat. Neurosci., 1(4), 271-272.

Haitina, T., Klovins, J., Andersson, J., Fredriksson, R., Lagerstorm, M.C., Larhammer, D., Larson, E.T., Schiöth, H.B. (2004) Cloning, tissue distribution, pharmacology and threedimensional modelling of melanocortin receptors 4 and 5 in rainbow trout suggest close evolutionary relationship of these subtypes. Biochem. J., 380, 475-486.

Halford, J.C., Cooper, G.D., Dovey, T.M. (2004) The pharmacology of human appetite expression. Curr. Drug Targets, 5(3), 221-240.

Hayashida, T., Murakami, K., Mogi, K., Nishihara, M., Nakazato, M., Mondal, M.S., Horii, Y., Kojima, M., Kangawa, K., Murakami, N. (2001) Ghrelin in domestic animals: distribution in stomach and its possible role. Domest. Anim. Endocrinol., 21(1), 17-24.

Heinrichs, S.C., Lapsansky, J., Behan, D.P., Chan, R.K., Sawchenko, P.E., Lorang, M., Ling, N., Vale, W.W., De Souza, E.B. (1996) Corticotropin-releasing factor-binding protein ligand inhibitor blunts excessive weight gain in genetically obese Zucker rats and rats during nicotine withdrawal. Proc. Natl. Acad. Sci. USA, 93(26), 15475-15480.

Heinrichs, S.C., Li, D.L., Iyengar, S. (2001) Corticotropin-releasing factor (CRF) or CRF bindingprotein ligand inhibitor administration suppresses food intake in mice and elevates body temperature in rats. Brain Res., 900(2), 177-185. 
Himick, B.A., Peter, R.E. (1994) CCK/gastrin-like immunoreactivity in brain and gut, and CCK suppression of feeding in goldfish. Am. J. Physiol., 267, R841-R851.

Himick, B.A., Vigna, S.R., Peter, R.E. (1996) Characterization of cholecystokinin binding sites in goldfish brain and pituitary. Am. J. Physiol., 271, R137-R143.

Hill, D.R., Campbell N.J., Shaw, T.M., Woodruff, G.N. (1987) Autoradiographic localization and biochemical characterization of peripheral type CCK receptors in rat CNS using highly selective nonpeptide CCK antagonists. J. Neurosci. 7, 2967-2976.

Hilton, J.W., Plisetskaya, E.M., Leatherland, J.F. (1987) Does oral 3,5,3'-triiodo-L-thyronine affect dietary glucose utilization and plasma insulin levels in rainbow trout Salmo gairdnerr? Fish Physiol. Biochem., 4, 113-120.

Horvath, T.L., Bechmann, I., Naftolin, F., Kalra, S.P., Leranth, C. (1997) Heterogeneity in the neuropeptide Y-containing neurons of the rat arcuate nucleus: GABAergic and non-GABAergic subpopulations. Brain Res. 756(1-2): 283-286.

Huising, M.O., Metz, J.R., van Schooten, C., Taverne-Thiele, A.J., Hermsen, T., Verburg-van Kemenade, B.M., Flik, G. (2004) Structural characterization of a cyprinid CRH, CRH-BP, and CRH-R1 and the role of these proteins in the acute stress response. J. Mol. Endocrinol., 32(3), 627-648.

Huising, M.O., Kruiswijk, C.P., Flik, G. (2006) Phylogeny and evolution of class-I helical cytokines. J. Endocrinol., 189(1), 1-25. 
Huszar, D., Lynch, C.A., Fairchild-Huntress, V., Dunmore, J.H., Fang, Q., Berkemeier, L.R., Gu, W., Kesterson, R.A., Boston, B.A., Cone, R.D., Smith, F.J., Campfield, L.A., Burn, P., Lee, F. (1997) Targeted disruption of the melanocortin-4 receptor results in obesity in mice. Cell, 88, $131-141$.

Iqbal, J., Kurose, Y., Canny, B., Clarke, I.J. (2006) Effects of central infusion of ghrelin on food intake and plasma levels of growth hormone, luteinizing hormone, prolactin, and cortisol secretion in sheep. Endocrinology, 147(1), 510-519.

Jensen, J. (2001) Regulatory peptides and control of food intake in non-mammalian vertebrates. Comp. Biochem. Physiol. A, 128, 471-479.

Johnsen, A.H. (1998) The phylogeny of the cholecystokinin/gastrin family. Front. Neuroendocrinol., 19, 73-99.

Johnson, R.M., Johnson, T.M., Londraville, R.L. (2000) Evidence for leptin expression in fishes. J. Exp. Zool., 286(7), 718-724.

Jonsson, A.C., Holmgren, S., Holstein, B. (1987) Gastrin/CCK-like immunoreactivity in endocrine cells and nerves in the gastrointestinal tract of the cod, Gadus morbua, and the effect of peptides of the gastrin/CCK family on cod gastrointestinal smooth muscle. Gen. Comp. Endocrinol., 66, 190-202.

Lederis, K., Letter, A., McMaster, D., Moore, G., Schlesinger (1982) Complete amino acid sequence of urotensin I, a hypertensive and corticotrophin-releasing factor neuropeptide from Catostomus. Science, 213(4514), 1394-1397. 
Kaiya, H., Kojima, M., Hosada, H., Riley, L.G., Hirano, T., Grau, E.G., Kangawa, K. (2003a) Identification of tilapia ghrelin and its effects on growth hormone and prolactin release in the tilapia, Oreochromis mossambicus. Comp. Biochem. Physiol. B Biochem. Mol. Biol., 135(3), 421-429.

Kaiya, H., Kojima, M., Hosada, H., Riley, L.G., Hirano, T., Grau, E.G., Kangawa, K. (2003b) Amidated fish ghrelin: purification, cDNA cloning in the Japanese eel and its biological activity. J. Endocrinol., 176(3), 415-423.

Kaiya, H., Kojima, M., Hosada, H., Moriyama, S., Takahashi, A., Kawauchi, H., Kangawa, K. (2003c) Peptide purification, complementary deoxyribonucleic acid (DNA) and genomic DNA cloning, and functional characterization of ghrelin in rainbow trout. Endocrinology, 144(12), $5215-5226$.

Kalra, S.P., Dube, M.G., Kalra, P.S. (1988) Continuous intraventricular infusion of neuropeptide Y evokes episodic food intake in satiated female rats: effects of adrenalectomy and cholecystokinin. Peptides, 9(4), 723-728.

Kalra, S.P., Dube, M.G., Sahu, A., Phelps, C.P., Kalra, P.S. (1991) Neuropeptide Y secretion increases in the paraventricular nucleus in association with increased appetite for food. Proc. Natl. Acad. Sci. USA, 88(23), 10931-10935.

Kalra, S.P., Dube, M.G., Pu, S., Xu, B., Horvath, T.L., Kalra, P.S. (1999) Interacting appetiteregulating pathways in the hypothalamic regulation of body weight. Endocr. Rev., 20, 68-100. 
Kastin, A.J., Pan, W., Maness, L.M., Koletsky, R.J., Ernsberger, P. (1999) Decreased transport of leptin across the blood-brain barrier in rats lacking the short form of the leptin receptor. Peptides, 20(12), 1449-1453.

Klovins, J., Haitina, T., Fridmanis, D., Kilianova, Z., Kapa, I., Fredriksson, R., Gallo-Payet, N., Shiöth, H.B. (2004) The melanocortin system in Fugu: determination of POMC/AgRP/MCR gene repertoire and synteny, as well as pharmacology and anatomical distribution of MCRs. Mol. Biol. Evol., 21, 563-579.

Kojima, M., Hosoda, M., Date, Y., Nakazato, M., Matsuo, H., Kangawa, K. (1999) Ghrelin is a growth-hormonereleasing acylated peptide from stomach. Nature, 402, 656-660.

Kojima, M., Kangawa, K. (2005) Ghrelin: structure and function. Physiol. Rev., 85(2), 495-522.

Kow, L., Pfaff, D. (1991) The effects of the TRH-metabolite cyclo(His-Pro) and its analogs on feeding. Pharmacol. Biochem. Behav., 38, 359-364.

Kristensen, P., Judge, M.E., Thim, L., Ribel, U., Christjansen, K.N., Wulff, B.S., Clausen, J.T., Jensen, P.B., Madsen, O.D., Vrang, N., Larsen, P.J., Hastrup, S. (1998) Hypothalamic CART is a new anorectic peptide regulated by leptin. Nature, 393, 72-76.

Kurokawa, T., Suzuki, T., Hashimoto, H. (2003) Identification of gastrin and multiple cholecystokinin genes in teleost. Peptides, 24, 227-235.

Kurokawa, T., Uji, S., Suzuki, T. (2005) Identification of cDNA coding for a homologue to mammalian leptin from pufferfish, Takifugu rubripes. Peptides, 26(5), 745-750. 
Lambert, P.D., Couceyro, P.R., McGirr, K.M., Dall Vechia, S.E., Smith, Y., Kuhar, M.J. (1998) CART peptides in the central control of feeding and interactions with neuropeptide Y. Synapse, 29(4), 293-298.

Larsen, P.J., Vrang, N., Petersen, P.C., Kristensen, P. (2000) Chronic intracerebroventricular administration of recombinant CART(42-89) peptide inhibits and causes weight loss in lean and obese Zucker (fa/fa) rats. Obes. Res., 8(8), 590-596.

Larsson, L.I., Rehfeld, J.F. (1978) Distribution of gastrin and CCK cells in the rat gastrointestinal tract. Evidence for the occurrence of three distinct cell types storing $\mathrm{COOH}$-terminal gastrin immunoreactivity. Histochemistry, 58, 23-31.

Lawrence, C.B., Snape, A.C., Baudoin, F.M., Luckman, S.M. (2002) Acute central ghrelin and GH secretagogues induce feeding and activate brain appetite centers. Endocrinology, 143(1), 155-162.

Leibowitz, S.F., Wortley, K.E. (2004) Hypothalamic control of energy balance: Different peptides, different functions. Peptides, 25(3), 473-504.

Lewis, K., Li, C., Perrin, M.H., Blount, A., Kunitake, K., Donaldson, C., Vaughan, J., Reyes, T.M., Gulyas, J., Fischer, W., Bilezikjian, L., Rivier, J., Sawchenko, P.E., Vale, W.W. (2001) Identification of urocortin III, an additional member of the corticotropin-releasing factor (CRF) family with high affinity for the CRF2 receptor. Proc. Natl. Acad. Sci. USA, 98(13), 7570-7575.

Little, T.J., Horowitz, M., Feinle-Bisset, C. (2005) Role of cholecystokinin in appetite control and body weight regulation. Obes. Rev., 6, 297-306. 
Lopez, M., Seoane, L., Tovar, S., Senaris, R.M., Dieguez, C. (2002) Thyroid status regulates CART but not AgRP mRNA levels in the rat hypothalamus. Neuroreport., 13(14), 1775-1779.

Lopez-Patino, M.A., Guijarro, A.I., Isorna, E., Delgado, M.J., Alonso-Bedate, M., De Pedro, N. (1999) Neuropeptide Y has a stimulatory action on feeding behaviour in goldfish (Carassius auratus). Eur. J. Pharmacol., 377, 147-153.

Lovett, D., Booth, D.A. (1970) Four effects of exogenous insulin on food intake. Q. J. Exp. Psychol., 22(3), 406-419.

MacNeil, D.J., Howard, A.D., Guan, X., Fong, T.M., Nargund, R.P., Bednarek, M.A., Goulet, M.T., Weinberg, D.H., Strack, A.M., Marsh, D.J., Chen, H.Y., Shen, C.P., Chen, A.S., Rosenblum, C.I., MacNeil, T., Tota, M., MacIntyre, E.D., van der Ploeg, L.H. (2002) The role of melanocortins in body weight regulation: opportunities for the treatment of obesity. Eur. J. Pharmacol., 440(2-3), 141-157.

Marsh, D.J., Hollopeter, G., Huszar, D., Laufer, R., Yagaloff, K.A., Fisher, S.L., Burn, P., Palmiter, R.D. (1999) Response of the melanocortin-4 receptor-deficient mice to anorectic and orexigenic peptides. Nature Gen., 21, 119-122.

Mazon, A.F., Verburg van Kemenade, B.M.L., Flik, G., Huising, M.O. (2006) Corticotropinreleasing hormone receptor 1 (CRH-R1) and CRH-binding protein (CRH-BP) are expressed in the gills and skin of common carp Cyprinus carpio L. and respond to acute stress and infection. J. Exp. Biol, 209, 510-517. 
Metz, J.R., Huising, M.O., Meek, J., Taverne-Thiele, A.J., Wendelaar Bonga, S.E.. Flik, G. (2004) Localisation, expression and control of adrenocorticotropic hormone in the nucleus preopticus and pituitary gland of common carp (Cyprinus carpio L.). J. Endocrinol., 182, 23-31.

Metz, J.R., Peters, J.J.M., Flik, G. (2006) Molecular biology and physiology of the melanocortin system in fish: a minireview. Gen. Comp. Endocrinol., in press.

Michaud, E.J., Bultman, S.J., Stubbs, L.J., Woychik, R.P. (1993) The embryonic lethality of homozygous lethal yellow mice (Ay/Ay) is associated with the disruption of a novel RNAbinding protein. Genes Dev., 7(7A), 1203-1213.

Miller, M.W., Duhl, D.M., Vrieling, H., Cordes, S.P., Ollmann, M.M., Winkes, B.M., Barsh, G.S. (1993) Cloning of the mouse agouti gene predicts a secreted protein. Genes Dev., 7(3), 454-467.

Mommsen, T.P., Plisetskaya, E.M. (1991) Insulin in fishes and agnathans: history, structure, and metabolic regulation. Rev. Aquat. Sci., 4, 225-259.

Moon, T.W., Foster, G.D., Plisetskaya, E.M. (1989) Changes in peptide hormones and liver enzymes in the rainbow trout deprived of food for 6 weeks. Can. J. Zool., 67, 2189-2193.

Moons, L., Batten, T.F.C., Vandesande, F. (1992) Comparative distribution of substance P (SP) and cholecystokinin (CCK) binding sites and immunoreactivity in the brain of the sea bass (Dicentrarchus labrax). Peptides, 13, 37-46.

Moran, T.H., Robinson, P.H., Goldrich, M.S., McHugh, P.R. (1986) Two brain cholecystokinin receptors: implications for behavioral action. Brain Res., 362, 175-179. 
Moran, T.H., Kinzig, K.P. (2004) Gastrointestinal satiety signals II. Cholecystokinin. Am. J. Physiol. Gastrointest. Liver Physiol., 286, G183-G188.

Mustonen, A.M., Nieminen, P., Hyvarinen, H. (2002) Leptin, ghrelin, and energy metabolism of the spawning burbot (Lota lota, L.). J. Exp. Zool., 293(2), 119-126.

Nakazato, M., Murakami, N., Date, Y., Kojima, M., Matsuo, H., Kangawa, K., Matsukura, S. (2001) A role for ghrelin in the central regulation of feeding. Nature, 409, 194-198.

Narnaware, Y.K., Peyon, P.P., Lin, X., Peter, R.E. (2000) Regulation of food intake by Neuropeptide Y in goldfish. Am. J. Physiol. Regul. Integr. Comp. Physiol., 279, R1025-R1034.

Narnaware, Y.K., Peter, R.E. (2001) Effects of food deprivation and refeeding on Neuropeptide Y (NPY) gene expression in goldfish. Comp. Biochem. Physiol. B, 129, 633-637.

Neary, N.M., Goldstone, A.P., Bloom, S.R. (2004) Appetite regulation: from the gut to the hypothalamus. Clin. Endocrinol., 60, 153-160.

Niswender, K.D., Baskin, D.G., Schwartz, M.W. (2004) Insulin and its evolving partnership with leptin in the hypothalamic control of energy homeostasis. Trends Endocrinol Metab., 15(8), 362 369.

Oliver, A.S., Vigna, S.R. (1996) CCK-X receptors in the endothermic mako shark (Isurus oxyrinchus). Gen. Comp. Endocrinol., 102, 61-73. 
Pandya, P.K., Huang, S.C., Talkad, V.D., Wank, S.A., Gardner, J.D. (1994) Biochemical regulation of three different states of the cholecystokinin (CCK) receptor in pancreatic acini. Biochim. Biophys. Acta, 1224, 117-126.

Panksepp, J., Reilly, P., Bishop, P., Meeker, R.B., Vilberg, T.R., Kastin, A.J. (1976) Effects of alpha-MSH on motivation, vigilance and brain respiration. Pharmacol. Biochem. Behav., 5, 59-64.

Peyon, P. Saied, H., Lin, X., Peter, R.E. (1999) Postprandial, seasonal and sexual variations in cholecystokinin gene expression in goldfish brain. Brain Res. Mol. Brain Res., 74, 190-196.

Qian, S., Chen, H., Weingarth, D., Trumbauer, M.E., Novi, D.E., Guan, X., Yu, H., Shen, Z, Feng, Y., Frazier, E., Chen, A., Camacho, R.E., Shearman, L.P., Gopal-Truter, S., MacNeil, D.J., Van der Ploeg, L.H., Marsh, D.J. (2002) Neither agouti-related protein nor neuropeptide Y is critically required for the regulation of energy homeostasis in mice. Mol. Cell. Biol., 22(14), 50275035.

Qu, D., Ludwig, D.S., Gammeltoft, S., Piper, M., Pelleymounter, M.A., Cullen, M.J., Mathes, W.F., Przypek, R., Kanarek, R., Maratos-Flier, E. (1996) Nature, 380, 243-247.

Rahmouni, K., Haynes, W.G. (2001) Leptin signalling pathways in the central nervous system: interactions between neuropeptide Y and melanocortins. Bioessays, 23, 1095-1099.

Rehfeld, J.F. (1981) Four basic characteristics of the gastrin-cholecystokinin system. Am. J. Physiol. Gastrointest. Liver Physiol., 240, 255-266. 
Rehfeld, J.F. (1998) Accurate measurement of cholecystokinin in plasma. Clin. Chem., 44, 9911001.

Richard, D., Huang, Q., Timofeeva, E. (2000) The corticotropin-releasing hormone system in the regulation of energy balance in obesity. Int. J. Obes. Relat. Metab. Disord., 24(S2), S36-S39.

Riley, L.G., Fox, B.K., Kaiya, H., Hirano, T., Grau, E.G. (2005) Long-term treatment of ghrelin stimulates feeding, fat deposition, and alters the GH/IGF-I axis in the tilapia, Oreochromis mossambicus. Gen. Comp. Endocr., 142, 234-240.

Rohner-Jeanrenaud, F., Walker, C.D., Greco-Perotto, R., Jeanrenaud, B. (1989) Central corticotropin-releasing factor administration prevents the excessive body weight gain of genetically obese (fa/fa) rats. Endocrinology, 124(2), 733-739.

Sahu, A., Kalra, P.S., Kalra, S.P. (1988) Food deprivation and ingestion induce reciprocal changes in the paraventricular nucleus. Peptides, 9(1), 83-86.

Saito, E.S., Kaiya, H., Takagi, T., Yamasaki, I., Denbow, D.M., Kangawa, K., Furuse, M. (2002) Chicken ghrelin and growth hormone-releasing peptide-2 inhibit food intake of neonatal chicks. Eur. J. Pharmacol., 453(1), 75-79.

Sakurai, T., Amemiya, A., Ishii, M., Matsuzaki, I., Chemelli, R.M., Tanaka, H., Williams, S.C., Richardson, J.A., Kozlowski, G.P., Wilson, S., Arch, J.R., Buckingham, R.E., Haynes, A.C., Carr, S.A., Annan, R.S., McNulty, D.E., Liu, W.S., Terett, J.A., Elshourbagy, N.A., Bergsma, D.J., Yanagisawa, M. (1998) Orexins and orexin receptors: a family of hypothalamic neuropeptides and G protein-coupled receptors that regulate feeding behavior. Cell, 92(4), 573-585. 
Schwartz, M.W., Sipols, A.J., Marks, J.L., Sanachora, G., White, J.D., Scheurink, A., Kahn, S.E., Baskin, D.G., Woods, S.C., Figlewicz, D.P., Porte Jr., D. (1992) Inhibition of hypothalamic neuropeptide Y gene expression by insulin. Endocrinology, 130(6), 3608-3616.

Schwartz, M.W., Baskin, D.G., Bukowski, T.R., Kuijper, J.L., Foster, D., Lasser, G., Prunkard, D.E., Porte, D., Woods, S.C., Seeley, R.J., Weigle, D.S. (1996) Specificity of leptin action on elevated blood glucose levels and hypothalamic neuropeptide Y gene expression in ob/ob mice. Diabetes, 45(4), 531-535.

Schwartz, M.W., Woods, S.C., Porte, D., Seeley, R.J., Baskin, D.G. (2000) Central nervous system control of food intake. Nature, 404, 661-671.

Schwartz, M.W., Woods, S.C., Seeley, R.J., Barsh, G.S., Baskin, D.G., Leibel, R.L. (2003) Is the energy homeostasis system inherently biased toward weight gain? Diabetes, 52, 232-238.

Seeley, R.J., Woods, S.C. (2003) Monitoring of stored and available fuel by the CNS: implications for obesity. Nat. Rev. Neurosci., 4(11), 901-9.

Silverstein, J.T. Wolters, W.R., Holland, M. (1999) Brain regulation of feeding behaviour and food intake in fish. J. Fish. Biol., 54, 607-615.

Silverstein, J.T., Plisetskaya, E.M. (2000) The effects of NPY and insulin on food intake regulation in fish. Am. Zool., 40, 296-308. 
Smith, S.M., Vaughan, J.M., Donaldson, C.J., Rivier, J., Li, C., Chen, A., Vale, W.W. (2004) Cocaine- and amphetamine-regulated transcript activates the hypothalamic-pituitary-adrenal axis through a corticotropin-releasing factor receptor-dependent mechanism. Endocrinology, 145(11), 5202-5209.

Soengas, J.L., Aldegunde, M. (2004) Brain glucose and insulin: effects on food intake and brain biogenic amines of rainbow trout. J. Comp. Physiol. A Neuroethol. Sens. Neural Behav. Physiol., 190(8), 641-649.

Somero, G.N., Suarez, R.K. (2005) Peter Hochachka: adventures in biochemical adaptation. Annu. Rev. Physiol., 67, 25-37.

Song, Y., Golling, G., Thacker, T.L., Cone, R.D. (2003) Agouti-related protein (AgRP) is conserved and regulated by metabolic state in the zebrafish, Danio rerio. Endocrine, 22, 257-265.

Spiegelman, B.M., Flier, J.S. (2001) Obesity and the regulation of energy balance. Cell, 104, 531543.

Spiess, J., Villarreal, J., Vale, W.W. (1981) Isolation and sequence analysis of a somatostatin-like polypeptide from ovine hypothalamus. Biochemistry, 20, 1982-1988.

Stanley, S.A., Small, C.J., Murphy, K.G., Rayes, E., Abbott, C.R., Seal, L.J., Morgan, D.G., Sunter, D., Dakin, C.L., Kim, M.S., Hunter, R., Kuhar, M., Ghatei, M.A., Bloom, S.R. (2001) Actions of cocaine- and amphetamine-regulated transcript (CART) peptide on regulation of appetite and hypothalamo-pituitary axes in vitro and in vivo in male rats. Brain. Res., 893(1-2), 186-194. 
Ste. Marie, L., Luquet, S., Cole, T.B., Palmiter, R.D. (2005) Modulation of neuropeptide Y expression in adult mice does not affect feeding. Proc. Natl. Acad. Sci. USA, 102(51): 1863218637.

Stephens, T.W., Basinski, M., Bristow, P.K., Bue-Vallesky, J.M., Burgett, S.G., Craft, L., Hale, J., Hoffmann, J., Hsiung, H.M., Hansen, M., Hsiung, A.K., MacKellar, W., Rosteck, P.R., Schoner, B., Smith, D., Tinsley, F.C., Zhang, X., Heiman, M. (1995) The role of neuropeptide Y in the antiobesity action of the obese gene product. Nature, 377, 530-532.

Sugino, T., Hasegawa, Y., Kikkawa, Y., Yamaura, J., Yamagishi, M., Kurose, Y., Kojima, M., Kangawa, K., Terashima, Y. (2002) A transient ghrelin surge occurs just before feeding in a scheduled meal-fed sheep. Biochem. Biophys. Res. Comm., 295(2), 255-260.

Sugino, T., Hasegawa, Y., Kurose, Y., Kojima, M., Kangawa, Terashima, Y. (2004) Effects of ghrelin on food intake and neuroendocrine function in sheep. Anim. Reprod. Sci., 82-83, 183194.

Thornton, J.E., Cheung, C.C., Clifton, D.K., Steiner, R.A. (1997) Regulation of hypothalamic proopiomelanocortin mRNA by leptin in ob/ob mice. Endocrinology, 138, 5063-5066.

Tschöp, M., Smiley, D.L., Heiman, M.L. (2000) Ghrelin induces adiposity in rodents. Nature, 407, 908-913.

Unniappan, S., Lin, X., Cervini, L., Rivier, J., Kaiya, H., Kangawa, K., Peter, R.E. (2002) Goldfish ghrelin: molecular characterization of the complementary deoxyribonucleic acid, partial gene structure and evidence for its stimulatory role in food intake. Endocrinology, 143(10), 4143-4146. 
Unniappan, S., Canosa, L.F., Peter, R.E. (2004) Orexigenic actions of ghrelin in goldfish: feedinginduced changes in brain and gut mRNA expression and serum levels, and responses to central and peripheral injections. Neuroendocrinology, 79(2), 100-108.

Van Dijk, G., Strubbe, J.H. (2003) Time-dependent effects of neuropeptide Y infusion in the paraventricular hypothalamus on ingestive and associated behaviors in rats. Physiol. Behav., 79(45), 575-580.

Van Enckevort, F.H., Pepels, P.P., Leunissen, J.A., Martens, G.J., Wendelaar Bonga, S.E., Balm, P.H. (2000) Oreochromis mossambicus (tilapia) corticotropin-releasing hormone: cDNA sequence and bioactivity. J. Neuroendocrinol., 12(2), 177-186.

Verbalis, J., Blackburn, R., Hoffman, G., Stricker, E. (1995) Establishing behavioural and physiological functions of central oxytocin: insights from studies of oxytocin and ingestive behaviours. Adv. Exp. Med. Biol., 395, 209-225.

Vergusdal, A., Sundvold, H., Gjoen, T., Ruyter, B. (2003) An in vitro method for studying the proliferation and differentiation of Atlantic salmon preadipocytes. Lipids, 38(3), 289-296.

Volkoff, H., Peter, R.E. (2000) Effects of CART peptides on food consumption, feeding and associated behaviors in the goldfish, Carassius auratus: actions on neuropeptide Y-and orexin Ainduced feeding. Brain. Res., 887(1), 125-133.

Volkoff, H., Peter, R.E. (2001) Characterization of two forms of cocaine- and amphetamineregulated transcript (CART) peptide precursors in goldfish: molecular cloning and distribution, 
modulation of expression by nutritional status, and interactions with leptin. Endocrinology, 142(12), 5076-5088.

Volkoff, H., Eykelbosch, A.J., Peter, R.E. (2003) Role of leptin in the control of feeding of goldfish Carassius auratus: interactions with cholecystokinin, neuropeptide $\mathrm{Y}$ and orexin $\mathrm{A}$, and modulation by fasting. Brain Res., 972(1-2), 90-109.

Volkoff, H., Canosa, L.F., Unniappan, S., Cerdá-Reverter, J.M., Bernier, N.J., Kelly, S.P., Peter, R.E. (2005) Neuropeptides and the control of food intake in fish. Gen. Comp. Endocr., 142, 319.

Wank, S.A., Harkins, R., Jensen, R.T., Shapira, H., de Weerth, A., Slatterly, T. (1992) Purification, molecular cloning, and functional expression of the cholecystokinin receptor from rat pancreas. Proc. Natl. Acad. Sci. USA, 89: 3125-3129.

Weatherford, S.C., Laughton, W.B., Salabarria, J., Danho, W., Tilley, J.W., Neterville, L.A., Schwartz, G.J., Moran, T.H. (1993) CCK satiety is differentially mediated by high- and lowaffinity CCK receptors in mice and rats. Am. J. Physiol. Regul. Integr. Comp. Physiol., 264, 244249.

Wendelaar Bonga, S.E. (1997) The stress response in fish. Physiol. Rev., 77(3), 591-625.

West, D.B., Fey, D., Woods, S.C. (1984) Cholecystokinin persistently suppresses meal size but not food intake in free-feeding rats. Am. J. Physiol. Regul. Integr. Comp. Physiol., 246, R776R787. 
Wilcox, B.J., Matsumoto, A.M., Dorsa, D.M., Baskin, D.G. (1989) Reduction of insulin binding in the arcuate nucleus of the rat hypothalamus after 6-hydroxydopamine treatment. Brain Res., 500(1-2), 149-155.

Wilding, J.P., Gilbey, S.G., Bailey, C.J., Batt, R.A., Williams, G., Ghatei, M.A., Bloom, S.R. (1993) Increased neuropeptide-Y messenger ribonucleic acid (mRNA) and decreased neurotensin mRNA in the hypothalamus of the obese (ob/ob) mouse. Endocrinology, 132(5), 1939-1944.

Woods, S.C., Lotter, E.C., McKay, L.D., Porte, D. (1979) Chronic intracerebroventricular infusion of insulin reduces food intake and body weight of baboons. Nature, 282, 503-505.

Xu, B., Kalra, P.S., Moldawer, L.L., Kalra, S.P. (1998) Increased appetite augments hypothalamic NPY Y1 receptor gene expression: effects of anorexigenic ciliary neutropic factor. Regul. Pept., 75-76, 391-395.

Yaghoubian, S., Filosa, M.F., Youson, J.H. (2001) Proteins immunoreactive with antibody against a human leptin fragment are found in serum and tissues of the sea lamprey, Petromyzon marinus L. Comp. Biochem. Physiol. B Biochem. Mol. Biol., 129(4), 777-785.

Zhang, Y., Proenca, R., Maffei, M., Barone, M., Leopold, L., Friedman, J.M. (1994) Positional cloning of the mouse obese gene and its human homologue. Nature, 372, 425-432

Zheng, H., Patterson, C., Berthoud, H.R. (2001) Fourth ventricular injection of CART peptide inhibits short-term sucrose intake in rats. Brain. Res., 896(1-2), 153-156. 


\section{Figure captions}

Figure 1: Overview of the regulation of food intake and body weight. In mammals (A), the effects of peripheral indicators of nutrient status with brain centers that regulate food intake are indicated. The ARC contains two distinct subsets of neurons that co-express either NPY and AgRP or CART and POMC, the former peptides increase, while the latter set decreases food intake. The ARC receives multiple endocrine input from the periphery, where leptin, insulin (that both circulate in proportion to body fat), ghrelin (expressed by the stomach wall in response to low carbohydrate levels in the stomach), and CCK (expressed by stomach endocrine cells in response to nutrient stimulation) relay information about nutrient status and energy reserves to the hypothalamus. The $\mathrm{NPY}^{+} / \mathrm{AgRP}^{+}$and $\mathrm{CART}^{+} / \mathrm{POMC}^{+}$neurons inhibit each other and signal to higher order neurons in the PVN, including CRH neurons. These CRH neurons project to the hindbrain, where (in combination with CCK) food intake is terminated. The differences in the regulation of feeding and energy metabolism in fish (B) compared to mammals are shown in italics and possible interactions that remain to be established are indicated by question marks. These differences include the nomenclature of the hypothalamic nuclei involved: the NLT and NPO instead of the ARC and PVN. Furthermore, in contrast to mammals where the adrenal gland produces glucocorticoids, the head kidney fulfils this function in fish. Fish leptin is expressed and produced mainly in the liver. Note that some fish species (including common carp) do not possess a classical stomach, the main site of ghrelin production in these species remains to be established. Abbreviations: ACTH: adrenocorticotropic hormone, AgRP: agouti related protein, ARC: arcuate nucleus, CART: cocaine and amphetamine regulated transcript, CCK: cholecystokinin, CRH: corticotropin releasing hormone, GC's: glucocorticoids, HPA-axis: hypothalamus-pituitary-adrenal axis, MSH: $\alpha$-melanocyte stimulating hormone, NLT: nucleus lateralis tuberis, NPO: nucleus preopticus, NPY: neuropeptide Y, PVN: paraventricular nucleus. 


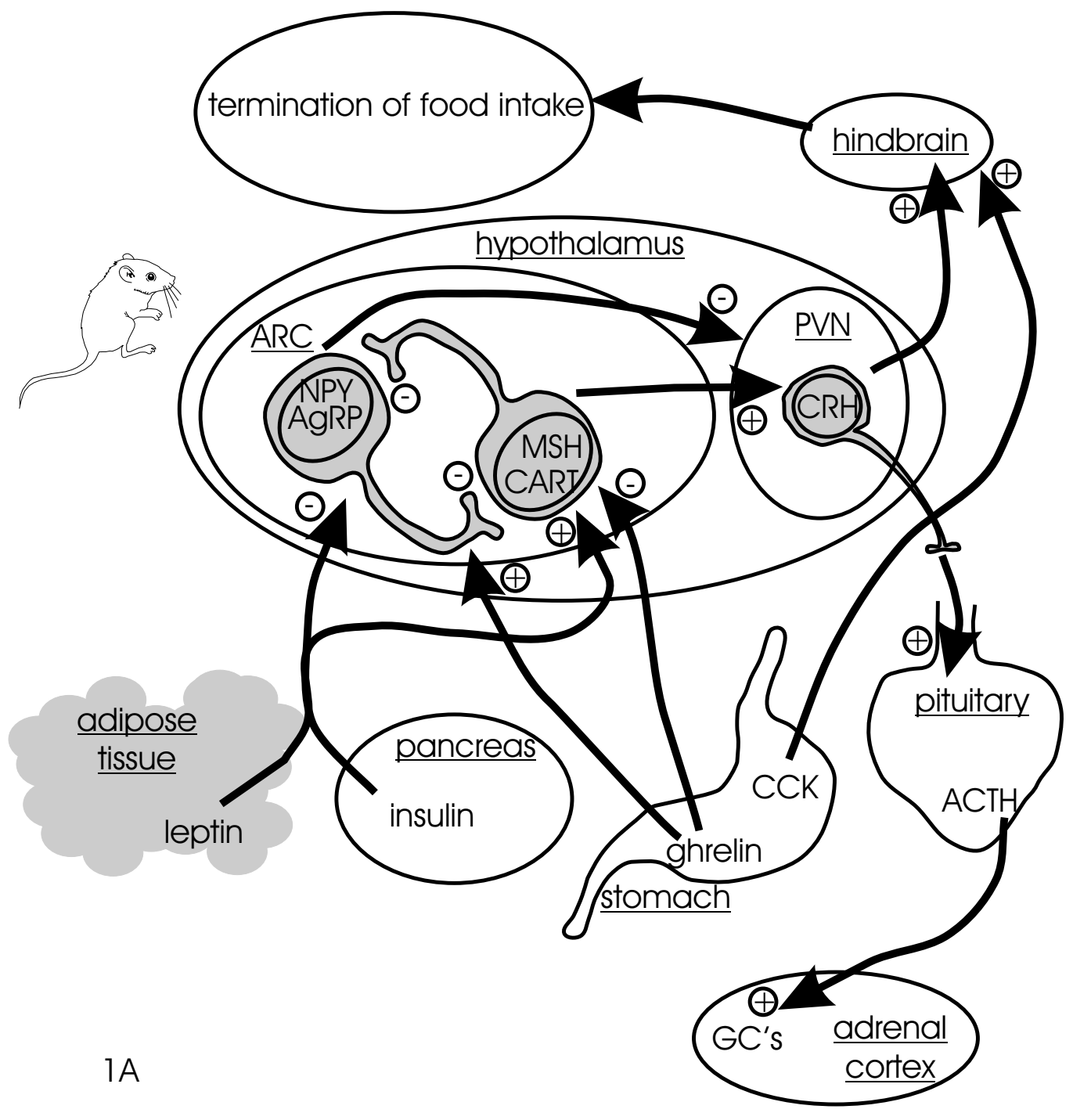




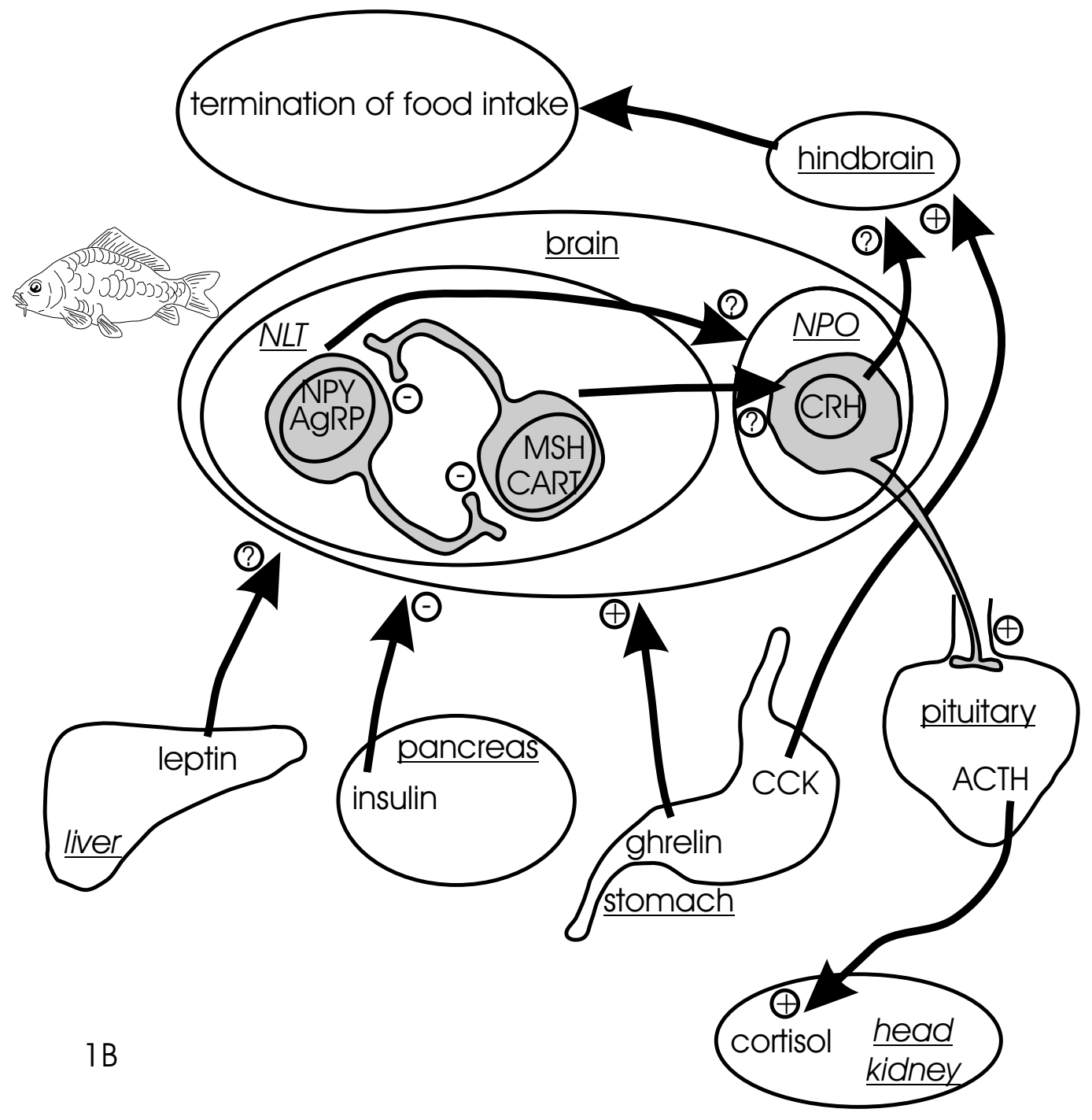

